\title{
MARKETING AND LOGISTICS: FEATURES OF FUNCTIONING DURING THE PANDEMIC
}

\author{
Hassan Ali Al- Ababneh \\ Faculty of Administrative and Financial Sciences - E - Marketing and Social Communication, Department of \\ International Marketing Economics, Irbid National University, Irbid Amman International Road - Near Naima Triangle, \\ 21110 Irbid, Jordan, hassan_ababneh@inu.edu.jo
}

Keywords: marketing, logistics, concept, management, pandemic

Abstract: The need to revise existing approaches and business strategies in logistics was identified in connection with global imbalances in the world economy against the background of the fight against the COVID-19 pandemic. The theory of the organization of marketing activities is considered, a critical analysis is carried out in order to determine the main components of the interaction between marketing and logistics. The lack of a unified approach to organizing effective marketing activities and its interaction with logistics during the COVID-19 pandemic is emphasized. The main components of the marketing concept of doing business have been substantiated. The functional areas of interaction between marketing and logistics in the world during the COVID-19 pandemic have been determined. The classification of the key factors that influenced the transformation of logistics activities in the world has been substantiated. Structural and logical analysis revealed the main trends in the development of the logistics industry in the world. The main tools of scenario economic and mathematical modelling are used to determine the features of the functioning of marketing and logistics during the COVID-19 pandemic and to determine the main trends in their development and interaction. Unlike existing approaches, the proposed one takes into account all the critical influencing factors in the context of COVID-19 and allows you to determine the prospects for the next few years. The main results of the research can be applied in the practical activities of organizations in the formation of development strategies and marketing concepts.

\section{Introduction}

Features of doing business in the context of global transformations under the influence of various factors, both internal and external, due to the need to ensure the effective operation of organizations and companies around the world. The formation and implementation of strategic areas related to logistics are the main elements of marketing activities of most global companies. Foreign companies apply logistics and goods marketing strategies, supply chain management concepts at the national, regional and global levels. Today, the activities of many companies and organizations, as never before, are confirmed by the impact of a number of different factors. On the one hand, the analysis of the main trends of changes in various markets shows a steady increase in competition and the intensity of competition in all sectors of the world economy during the COVID-19 pandemic. However, the exacerbation of global imbalances caused by massive constraints in the fight against the spread of the pandemic poses strategic challenges to companies around the world, which are associated with the desire to gain a stable and long-term advantage over competitors with the need to achieve the highest efficiency. On the other hand, many companies and organizations are subject to the daily resolution of contradictions due to the imperfection of existing economic models, which are expressed in the specifics of the organization of their activities, taking into account modern restrictive measures related to the COVID-19 pandemic. In modern conditions, despite the existing measures to limit the economic activities of companies and organizations in a pandemic, the main goal for each company is to meet consumer needs to maximize profits by promoting their products using an effective marketing concept. In a pandemic, the focus of companies and organizations in the global market is on ensuring the effective use of existing capacity, taking into account key factors of influence.

This approach ensures companies' financial stability and long-term development, despite the existing limitations and the reduction in the number of consumers with the intensive development of innovative technologies. Management of companies arises when top management decides when a new order of relations is developed to overcome the problematic situations associated with the restrictive measures of the COVID-19 pandemic when new links are established between structural units related to organizational structure modification. One of the most effective tools (methods) of company management in modern realities are logistics and marketing. However, the functional interaction of marketing and logistics in a pandemic is quite relevant and requires more detailed research. It should be noted that comprehensive practical studies addressing the interaction of marketing and logistics in a COVID-19 pandemic are insufficient, as there are no theoretical and methodological aspects to identify major trends in marketing and logistics, which requires more detailed study and in-depth study. These aspects are a key prerequisite for a more detailed study of the main aspects of marketing and logistics' functioning in a pandemic. The relevance and practical need to determine 
the main features of the interaction of marketing and logistics and the lack of developed scientific and methodological approaches to the study of this issue predetermine the study's main purpose and key objectives.

The processes of globalization of the world economy increase the need to find innovative ways and forms of the business organization under the influence of restrictive measures of the pandemic. These processes significantly complicate the relationship between the participants in production, distribution, and exchange processes due to a number of systemic changes and trends in the world economy, which requires the application and use of more innovative approaches to management. Logistics is no exception and requires the use of innovative tools in their activities. In modern conditions, the interaction of marketing and logistics in a pandemic is due to a holistic process: production-supply-distribution-sales. However, despite the above, the transformation of marketing under the influence of significant factors due to global imbalances caused by the pandemic is quite acute.

\subsection{Marketing and logistics: theoretical aspects of functioning and features of interaction}

The theoretical aspects of the organization of marketing activities are disclosed in scientific works [1-6], which examine the historical moments of the formation of marketing as a key element of the company's strategic management. It should be noted that this approach is fundamental and laid the first steps in the development of marketing as the main set of elements that ensure the interaction of all structural divisions of the company in order to maximize the financial result. Despite the formed theoretical aspects, which consist in the formation of a simple marketing complex: product, price, sales and offer, it should be noted that these approaches do not focus on the need to analyze factors that can significantly affect the marketing mix, which is unacceptable in modern conditions of a pandemic and requires more in-depth research.

Analyzing the scientific literature and research in the field of marketing and the formation of its key components, it is worth highlighting the works [7-10], which, in contrast to existing approaches, consider the peculiarities of organizing the marketing mix taking into account the time factor and offer more advanced approaches that include such elements, like: product, price, sales, offer and environment.

The presented approaches are fundamental in the field of marketing development, since they expanded the standard set of key components and made it possible to take into account the factors that can influence the process of the company's functioning. However, this approach does not consider the peculiarities of the interaction of marketing and logistics as an integral mechanism, which requires further research. It should be noted that the modern market does not stand still and is subject to constant and continuous transformations under the influence of various global factors, which therefore causes many companies around the world to constantly develop and improve their mechanisms and approaches in promoting their products and brand of the company by transforming marketing elements in order to increase consumer loyalty: the implementation of online catalogues, online delivery and optimal logistics.

Maintaining competitiveness, forming and increasing competitive advantage, thereby ensuring a sufficiently high level of profit in the context of the COVID-19 pandemic, is possible only by applying in practice the concept of marketing, which allows satisfying the demands and needs of consumers in a combination of quality and price, and logistics in terms of optimizing commodity and material flows [8]. It should be noted that the main issues of interaction between two concepts of company management, which have proven their effectiveness in a free market - marketing and logistics - have recently received increased attention, as evidenced by a number of publications in the scientific literature.

Many domestic and foreign scientists [7-12] covered the issues of interaction between marketing and logistics, and the results of their integration in the activities of companies, to one degree or another, in their works. However, the majority of authors consider marketing and logistics as independent areas of production and economic activity, closely related to each other. Based on this, it is worth noting that in the scientific literature, special attention should be paid to the work of a group of scientists such as: [10-12], who expanded the marketing complex taking into account all modern trends, which includes: product, price, promotion, place sales, environment, people, process.

The presented approach is the closest to modern realities, but it does not consider the conceptual features of the functioning of marketing in the world and its interaction with logistics in a pandemic, which determines the relevance of the research topic and requires a deeper study. It should be noted that in the context of the pandemic, many companies around the world were placed in a very strict framework, which was based on strict restrictions on activities in order to reduce the social distance of the population and minimize the risks of the spread of the COVID-19 pandemic and did not allow fullfledged activities, which in turn affected the financial stability of both an individual company and the global economy as a whole. Based on this, it is worth noting that the transformation of the world market has led to a revision of the existing management approaches in order to improve and optimize those using innovative technologies and tools, which is reflected in the areas of marketing and its interaction with logistics.

Using marketing tools, a company can determine "its" consumers, namely who they are, what their needs are, in what quantity and what quality goods they need, what is a substitute for these goods and, in the end, receive recommendations on how to build the company's activities 
in order to tie them to it consumers. Logistics tools are designed, first, to organize the movement of commodity and material rationally flows at the enterprise, which will allow you to receive the timely delivery of finished products to the consumer at the right place, at the right time, in the right quantity and quality with minimal costs. As you can see, both of these tools in the organization's activities solve different functional tasks and in no way replace each other. Rather, on the contrary, only their joint use can guarantee the efficiency of the enterprise [8-9].

Although, in essence, both marketing and logistics companies can use in their activities independently of each other. So, using only a marketing concept, a company will not be able to effectively organize the promotion of its goods on the market since unresolved logistics issues of delivery, transportation, storage of goods can hinder this. In modern conditions of market saturation and global transformations caused by the COVID-19 pandemic, when the traditional motivational criteria of the consumer (quality and price of goods) fade into the background, these issues become almost decisive when the consumer makes a purchase decision. A similar situation develops when the marketing concept is ignored in the company's activities, since the logistics tasks cannot, in turn, be effectively implemented without marketing support. Thus, marketing and logistics cannot be separated from each other, since together they form the general conditions and policies of the enterprise's production, supply, and sales activities. Skilful use of both concepts simultaneously gives a much greater synergistic effect than the use of each concept separately [10-12].

There is a lot of discussion about the interaction of marketing and logistics. It is in the framework of clarifying the issue, hierarchy and priority of concepts, which inevitably leads to a dead end. The issue of delimiting the areas of competence of marketing and logistics is especially acute in conditions of limited company resources, when the choice of which of the two concepts should be preferred? Especially in extreme conditions such as activity restrictions and global quarantine measures. It is worth noting that an answer to this question can be obtained by analyzing the functional areas of the collision or intersection of interests of the two concepts and determining on its basis the mechanism of their interaction, which are presented in Table 1.

Table 1 Structuring the functionality and features of the interaction of marketing and logistics in the context of the COVID-19 pandemic

\begin{tabular}{|c|c|c|c|}
\hline \multirow{2}{*}{$\begin{array}{c}\text { Marketing concept } \\
\text { element }\end{array}$} & \multicolumn{2}{|c|}{ Functional features } & \multirow{2}{*}{ Interaction area } \\
\hline & marketing & logistics & \\
\hline \multirow{3}{*}{ Production } & $\begin{array}{l}\text { determination of subject } \\
\text { specialization and assortment } \\
\text { structure of production; }\end{array}$ & $\begin{array}{l}\text { identification of potential } \\
\text { sources of supply; }\end{array}$ & \multirow{3}{*}{ packing goods } \\
\hline & $\begin{array}{l}\text { determination of the } \\
\text { characteristics and physical } \\
\text { properties of the goods; }\end{array}$ & $\begin{array}{l}\text { rational organization of } \\
\text { production; }\end{array}$ & \\
\hline & $\begin{array}{l}\text { improving the quality and } \\
\text { competitiveness of goods }\end{array}$ & marketing policy management & \\
\hline price policy & $\begin{array}{l}\text { choice of strategy and method } \\
\text { of pricing }\end{array}$ & $\begin{array}{l}\text { reduction of costs in } \\
\text { distribution channels }\end{array}$ & $\begin{array}{l}\text { setting a competitive } \\
\text { price }\end{array}$ \\
\hline \multirow{5}{*}{ sales policy } & $\begin{array}{l}\text { market segmentation and } \\
\text { selection of the target segment; }\end{array}$ & $\begin{array}{l}\text { rationing of stocks of finished } \\
\text { products; }\end{array}$ & \multirow{5}{*}{$\begin{array}{l}\text { conditions for the } \\
\text { availability of goods to } \\
\text { the consumer; } \\
\text { formation of } \\
\text { distribution system; } \\
\text { the choice of channels } \\
\text { for the distribution of } \\
\text { finished products; } \\
\text { sales analysis; } \\
\text { service maintenance }\end{array}$} \\
\hline & search for potential consumers; & $\begin{array}{l}\text { creation of a storage system, } \\
\text { cargo handling; }\end{array}$ & \\
\hline & $\begin{array}{l}\text { demand generation and sales } \\
\text { promotion; }\end{array}$ & $\begin{array}{l}\text { selection of an effective option } \\
\text { for transporting products to the } \\
\text { end consumer; }\end{array}$ & \\
\hline & $\begin{array}{l}\text { study and forecasting of } \\
\text { demand; }\end{array}$ & \multirow{2}{*}{$\begin{array}{l}\text { development of cost estimates } \\
\text { for sales and control over its } \\
\text { observance }\end{array}$} & \\
\hline & sales forecasting & & \\
\hline \multirow[b]{2}{*}{ Information system } & $\begin{array}{l}\text { formation of a marketing } \\
\text { information system; }\end{array}$ & $\begin{array}{l}\text { formation of a logistics } \\
\text { information system; }\end{array}$ & \multirow{2}{*}{$\begin{array}{l}\text { justification and } \\
\text { organization of } \\
\text { information support for } \\
\text { the sales system }\end{array}$} \\
\hline & marketing research & $\begin{array}{l}\text { organization of effective } \\
\text { management of information } \\
\text { flows }\end{array}$ & \\
\hline
\end{tabular}

The modern market is significantly different from what existed 5 years ago. Today, the consumer is a direct participant in the value chain, which is reflected in the individualization of products and their globalization into 
the global space, taking into account all the restrictive measures of the pandemic. For the manufacturer, it becomes profitable to serial production, focused on the individual consumer with the possibility of sales taking into account modern realities.

The process of selling products has also become more complicated, which today cannot be imagined without CRM order processing systems, online platforms for ordering and delivering goods with a whole range of other logistics services. The application of the logistics concept in these conditions allows us to meet the individual needs in the quantity, timing and place of delivery of each consumer, standardizing them in a certain way.

Historically, marketing began earlier than logistics. The preconditions for the emergence of the concept were associated primarily with unorganized competition, ignoring the needs of the consumer and, as a consequence, with the difficulties encountered by manufacturers with the sale of goods. The use, at that time, of marketing contributed to the regulation of the relationship between the seller and the buyer, between the manufacturer and the consumer. In today's pandemic, it is no longer possible to achieve serious competitive advantages only through the use of marketing. It is no longer enough to identify potential consumer demand with the help of marketing tools; it is necessary to turn it into real demand, which must be satisfied in a timely manner. The fast and accurate delivery of goods to the consumer, which is possible only with well-established logistics, becomes one of the competitive advantages and ways of gaining customer loyalty.

Companies that have built their activities on the basis of a marketing concept sooner or later come to the need to create a logistics system that will optimize many processes, especially taking into account the global constraints associated with the COVID-19 pandemic. By improving the quality of logistics processes and increasing the depth of its integration with other management functions, the company gains additional competitive advantages, allowing it to occupy a more stable position in the market.

\subsection{Logistics in the world: the main prospects for development and current trends}

The pandemic has caused significant financial losses to the world economy and has hit hard on logistics and supply of raw materials and finished products. However, it is worth noting that the ability to adapt quickly to changing circumstances can help many companies recover quickly after a pandemic.

The crisis caused by global uncertainty, panic, and unpreparedness for drastic changes in the world economic structure initiated an imbalance in freight flows due to changes in demand, suspension of production organizations, and certain restrictions.

In view of the current situation, the governments of most countries, together with international companies, have set themselves the main tasks of stabilizing economies and supporting their continued operation and the stability of supply chains. It is worth noting that the global imbalances in the world economy exacerbated by massive restrictions related to the pandemic, which caused chaos and panic among the countries of the world, the goals aimed at stabilizing the economy and its long-term development remained necessary and relevant [13].

The pandemic has significantly transformed most companies around the world. It should be noted that the logistics industry has also transformed and will no longer be the same as before.

Many changes have made the companies cardinally to revise the way of activity and peculiarities of functioning in order to fulfil strategic tasks, namely: production of goods, their promotion, drawing up a pricing policy and further logistics, taking into account the need to optimize existing business processes of companies and maximum automation to reduce physical contacts of people and compliance with quarantine restrictions and sanitary standards. After the spread of the pandemic subsided, many companies began to conduct a detailed analysis of the current conditions of operation in the market, identifying key trends, studying consumer behaviour and their main preferences for the implementation of maximum personalization and retention of the customer base, which is quite important in the face of increasing competition in world markets.

It should be noted that the world economy during the pandemic was significantly dependent on logistics on a global scale. This fact contributed to the transformation of organizing logistics activities in the world and its mass collaboration to survive in the market and strengthen its position by offering relevant services using modern digital technologies. In the context of a post-demotic peak in the global economy, it should be noted that it is the collaboration of logistics companies into a single complex that will make it possible to become the most stable and effective drivers for the subsequent promising development and growth in the global scale of logistics services.

However, the presented transformations and collaborations cannot be imagined without substantial support and strategic interaction of other equally important market players in order to develop a comprehensive action plan to combat the consequences of the crisis phenomena caused by the coronavirus pandemic. This combination of efforts has also significantly influenced the building of partnerships and the revision of responsibilities for them, taking into account current trends that significantly impact the field of logistics services.

Based on this, it is worth arguing that trends will affect all areas of companies, especially in the field of logistics, regardless of the situation in the world, which are presented in more detail in Table 2. 
MARKETING AND LOGISTICS: FEATURES OF FUNCTIONING DURING THE PANDEMIC

Hassan Ali Al- Ababneh

Table 2 Classification of trends that affect the logistics of companies during the COVID-19 pandemic

\begin{tabular}{|c|c|}
\hline Main trends of influence & Characteristics and features of the functioning of logistics \\
\hline $\begin{array}{l}\text { Dumping in the logistics } \\
\text { market }\end{array}$ & $\begin{array}{l}\text { The intensification of the struggle for the customer leads to the emergence of } \\
\text { price dumping in the freight market, as the number of goods decreases and } \\
\text { transport is idle. Many companies will not withstand prolonged dumping during } \\
\text { a pandemic. }\end{array}$ \\
\hline Tough competition & $\begin{array}{l}\text { The pandemic has intensified competition in the field of logistics services, which } \\
\text { in turn has forced small and some medium-sized companies to leave the market. } \\
\text { This aspect indicates that a series of bankruptcies, mergers and acquisitions will } \\
\text { begin in the near future. }\end{array}$ \\
\hline $\begin{array}{l}\text { Development of } \\
\text { collaborations, cooperation, } \\
\text { integration of services }\end{array}$ & $\begin{array}{l}\text { Logistics and service companies are starting to collaborate, develop unique } \\
\text { complex offers for customers and, as a result, strengthen their joint positions by } \\
\text { combining their services. }\end{array}$ \\
\hline $\begin{array}{l}\text { Increased demand for repair } \\
\text { and maintenance services for } \\
\text { vehicle fleets }\end{array}$ & $\begin{array}{l}\text { Refusal to renew the vehicle fleet due to the rise in the exchange rate and the } \\
\text { pandemic is observed in } 90 \% \text { of logistics companies. This led to the growth of } \\
\text { services related to the repair and maintenance of vehicle fleets. }\end{array}$ \\
\hline $\begin{array}{l}\text { Implementation of the latest } \\
\text { IT technologies }\end{array}$ & $\begin{array}{l}\text { During the pandemic, many companies decided to transfer all work to innovative } \\
\text { IT platforms for logistics companies in order to exchange tariffs and rates. }\end{array}$ \\
\hline $\begin{array}{l}\text { Development of domestic } \\
\text { cargo transportation and } \\
\text { supply chains }\end{array}$ & $\begin{array}{l}\text { The pandemic gave impetus to the development of the domestic product, the } \\
\text { development of industries within the country. A significant decrease in freight } \\
\text { flows from other Asian countries and the threat of closing borders with China in } \\
\text { the event of the next wave of a pandemic led to the fact that some of the resources, } \\
\text { goods, products that were previously purchased there, manufacturers began to } \\
\text { produce in their country. }\end{array}$ \\
\hline Outsourcing development & $\begin{array}{l}\text { The trend of outsourcing non-core processes and services is gaining momentum } \\
\text { in trade. }\end{array}$ \\
\hline Contactless courier delivery & $\begin{array}{l}\text { Contactless delivery - taking care of the health of senders and recipients. The end } \\
\text { consumer is offered the widest range of goods with contactless home delivery. }\end{array}$ \\
\hline $\begin{array}{l}\text { Development of parcel } \\
\text { delivery by drones. } \\
\text { Development of "autopilot" } \\
\text { deliveries }\end{array}$ & $\begin{array}{l}\text { This trend came from Asia as a continuation of the idea of contactless delivery. } \\
\text { During the pandemic in China, most parcels were delivered "to your home" in } \\
\text { this way. }\end{array}$ \\
\hline $\begin{array}{c}\text { Transfer of the majority of } \\
\text { employees on a permanent } \\
\text { basis to remote work }\end{array}$ & $\begin{array}{l}\text { This will require optimization and automation of all business processes of the } \\
\text { logistics operator. }\end{array}$ \\
\hline $\begin{array}{l}\text { Translation of all global } \\
\text { logistics events into an online } \\
\text { format }\end{array}$ & $\begin{array}{l}\text { The trend for most events in the logistics sector in the online format will continue, } \\
\text { because this format of meetings, negotiations, webinars, conferences has shown } \\
\text { high efficiency. }\end{array}$ \\
\hline $\begin{array}{l}\text { Logistics companies must } \\
\text { develop an anti-crisis plan }\end{array}$ & $\begin{array}{l}\text { The experience of the crisis during a pandemic will determine the management } \\
\text { of logistics companies to develop anti-crisis measures for organizations. }\end{array}$ \\
\hline
\end{tabular}

Based on the presented trends, which have a significant impact on the process of organizing logistics services, it should be noted that in order to get out of the crisis state of the logistics industry in all large countries of the world, state support measures are being actively implemented. It should be noted that, as a rule, support is provided to the public transport sector (railways, aviation, shipping, etc.).

However, government support can be provided to the commercial sector by introducing tax holidays, cancelling or reducing road tolls, and financial assistance to companies that have suffered large losses due to the pandemic. This support is very important if we consider road transportation, then there is a weighty help in reducing the cost of spare parts for vehicles by reducing import duties or tax rates for this group of goods. Very effective measures in some countries include a moratorium on fines (other than fines regulating road safety), abolishing the collection of tolls on federal highways, tax exemptions for the most vulnerable carriers, and suspension of lease payments without fines [13-14].

The provided support will allow this industry to significantly recover, revise its approaches to organizing effective work and build more sustainable development strategies, taking into account the main development trends in the world market and factors that have a significant impact. Consolidating the presented, it should be noted that in the modern world in the conditions of crisis, the phenomenon caused by a pandemic is quite important and relevant to build an effective marketing strategy with optimal interaction with the logistics industry. 


\section{Methodology}

\section{Peer Review Process}

The transformation of the global financial market under the influence of the crisis phenomena caused by the COVID-19 pandemic creates massive uncertainty, which significantly complicates the activities of companies and the conditions for doing business. In order to determine the main aspects of the functioning of marketing and its interaction with logistics during the pandemic, tools for critical analysis of existing scientific approaches were used. For the formation of scientific and methodological aspects of the interaction of marketing and logistics, the existing approaches to the construction of marketing strategies with various sets of complex elements are considered. The presented allowed us to highlight the existing marketing concepts in the world with a different complex of elements, but they do not reveal the peculiarities of the interaction between marketing and logistics, which proves the absence of a unified scientific approach and requires a more detailed study. With the help of structural and logical analysis, the key trends in the development of the logistics industry are identified, highlighting the main trends in the development of the logistics industry in the world. It has been reported that determining the features of the functioning of marketing and logistics during the COVID-19 pandemic and determining the main trends in their development and interaction is conceptually necessary to use scenario economic and mathematical modelling with a step-by-step construction of development scenarios and construct a further forecast of future growth. The proposed methodology for the first time takes into account the factors of influence in the conditions of COVID-19 and allows you to determine the prospects for the next few years, according to the developed theoretical rules.
The main results of the study can be applied in the practical activities of organizations in the formation of a development strategy and marketing concept. The methodological and practical component was the indicators of the dynamics of the development of logistics services and marketing in the world during the COVID-19 pandemic. Scenarios of economic and mathematical modelling and forecasting have been developed that will make it possible to identify the key influencing factors that have a significant impact on the processes of organizing the marketing activities of companies around the world. The main results can be applied in the practice of many companies in the formation of the marketing concept and identification of the key links of interaction with the logistics industry.

\section{Result and discussion}

In modern conditions, there is an intensive development of certain sectors of the world economy under the influence of the crisis phenomena caused by restrictions on combating the pandemic. The development of logistics services and transport forwarding is taking place at a rapid pace. The growing demands of cargo owners, a high level of competition in the industry and relationships with the external environment require transport enterprises to search for new ways of development, search and use new approaches and tools to attract and maintain their customers. The need to develop the freight forwarding services market is obvious.

The transformation of the world market and global changes have clearly demonstrated the vital importance of the logistics industry. However, its impact on logistics companies differs depending on the types of goods transported and the industries served. Characteristics of the features of the functioning of the logistics industry in the world during a pandemic are presented in Table 3.

Table 3 Structuring the peculiarities of the functioning of the logistics industry in the world

\begin{tabular}{|c|l|}
\hline Logistics type & Features of the functioning of the logistics industry \\
\hline Road transportation & $\begin{array}{l}\text { With the spread of the pandemic, the massive closure of factories and plants has led to } \\
\text { a gradual decline in the relevance of transport as an element of logistics. }\end{array}$ \\
\hline Air transportation & $\begin{array}{l}\text { The cancellation of passenger flights also affected the cost of cargo delivery services, } \\
\text { since most of them were previously delivered by passenger aircraft. This fact led to an } \\
\text { increase in more than 2 times the cost of logistics services. }\end{array}$ \\
\hline Shipping & $\begin{array}{l}\text { Marine logistics, despite all the difficulties associated with restrictions, continues to } \\
\text { work as usual. The logistics industry faced the problem of the lack of return containers, } \\
\text { which affected the cost of export and its rise in price - it became necessary to organize } \\
\text { direct flights for the supply of goods. }\end{array}$ \\
\hline Rail transportation & $\begin{array}{l}\text { The pandemic caused a decrease in the volume of railway traffic due to a global } \\
\text { decrease in trade turnover, but the speed of delivery of goods increased, since there } \\
\text { was no passenger traffic, which made it possible to increase the throughput of roads. }\end{array}$ \\
\hline
\end{tabular}

The global transformation of the global financial market under the influence of restrictions associated with the COVID-19 pandemic has radically changed the life of the world's population and the overall situation in the global and local markets. Around the world, there has been a significant reduction in production capacity due to the closure of borders between countries and the introduction of a self-isolation regime. The coronavirus pandemic has 
disrupted the familiar ties between manufacturers and consumers and has made major business changes for logistics companies. It should be noted that the spread of the coronavirus has dealt a serious blow to global logistics and supply chain security for raw materials and finished products. The aggravation of the crisis in the world economy caused a significant imbalance in freight traffic associated with changes in demand, the suspension of production and the imposed restrictions. In this regard, problems with the highest priority in maintaining the continuity and strength of supply chains have become the priority and most significant for the governments of states and international organizations.

It should be noted that despite the aggravation of the crisis in the world associated with the COVID-19 pandemic, the marketing activities of many companies and organizations were a key priority in ensuring uninterrupted work, an effective promotion system and logistics organization. It is important to note that the supply chains continued to function despite the restrictions, and the supply of FMCG products did not stop [14]. The crisis clearly demonstrated the vital importance of the logistics industry and made it possible to identify the key issues that need to be addressed when shaping a sales, management and logistics strategy. The transformation of the world market and individual industries also led to significant changes in logistics activities, which led to a revision of existing approaches to organizing logistics with the need to consider influencing factors. However, this transformation significantly complicated the existing processes in the logistics of organizations around the world, which were caused by the fact that many were not ready for such changes. The main factors that influenced the transformation of the logistics activities of organizations in a pandemic are presented in Table 4 .

Table 4 Classification of key factors that influenced the transformation of logistics activities in the world

\begin{tabular}{|c|c|c|}
\hline Key factor & Features of influence & Result of transformation of logistics activities \\
\hline Increased demand & $\begin{array}{l}\text { The pandemic caused a sharp increase in } \\
\text { demand for some categories of goods, and } \\
\text { a drop in demand for others, which was } \\
\text { not factored into the planning of logistics. } \\
\text { This led to supply disruptions, unclaimed } \\
\text { inventory and the need to optimize } \\
\text { logistics processes. }\end{array}$ & $\begin{array}{l}\text { When forming a company's strategy for the } \\
\text { promotion and sale of goods and services, it is } \\
\text { imperative to forecast demand and optimize } \\
\text { existing processes by means of their } \\
\text { automation. }\end{array}$ \\
\hline $\begin{array}{l}\text { Lack of supplier } \\
\text { diversification }\end{array}$ & $\begin{array}{l}\text { Sharp changes in the global market also } \\
\text { required quick adaptations of supply } \\
\text { chains and logistics categories of goods. } \\
\text { Many companies whose strategy } \\
\text { depended on direct supply were forced to } \\
\text { reallocate resources. }\end{array}$ & $\begin{array}{l}\text { When forming a company's strategy for the } \\
\text { promotion and sale of goods and services, it is } \\
\text { imperative to diversify suppliers in order to } \\
\text { minimize risks. }\end{array}$ \\
\hline $\begin{array}{l}\text { Increased load on } \\
\text { the organization of } \\
\text { logistics }\end{array}$ & $\begin{array}{l}\text { The increase in demand for certain } \\
\text { categories of goods has increased the } \\
\text { burden on logistics. Companies are faced } \\
\text { with the need to reallocate resources and } \\
\text { look for additional carriers. This load } \\
\text { demonstrated the need to optimize } \\
\text { logistics processes. }\end{array}$ & $\begin{array}{l}\text { The need to optimize logistics processes with } \\
\text { their subsequent automation in order to reduce } \\
\text { the time for collecting orders and the time of } \\
\text { delivery of goods. }\end{array}$ \\
\hline $\begin{array}{l}\text { The need to } \\
\text { automate the } \\
\text { business processes } \\
\text { of organizations } \\
\text { and companies }\end{array}$ & $\begin{array}{l}\text { The inefficiency of the existing logistics } \\
\text { processes was caused by a sharp increase } \\
\text { in demand and the inability to efficiently } \\
\text { manage the processes of interaction both } \\
\text { within the company and outside it. }\end{array}$ & $\begin{array}{l}\text { Revision of existing interaction processes } \\
\text { within the framework of the organization of } \\
\text { logistics with the automation of the process of } \\
\text { analyzing the customer base and the volume of } \\
\text { purchases with further consideration in the } \\
\text { formation of the organization's strategy. }\end{array}$ \\
\hline
\end{tabular}

The main factors affecting the transformation of the logistics industry in the world are caused by the spread of the COVID-19 pandemic, which has dealt a serious blow to global logistics and the supply chain of raw materials and finished products. The uninterrupted functioning of this area of the world economy during the pandemic was possible only with the support of the governments of many countries and international organizations. Global imbalances in freight traffic around the world associated with a sharp increase in demand, the suspension of production and the introduction of organizational arrangements have significantly affected the economic growth on a global scale [15]. The presented imbalances and factors that caused the transformation of the logistics industry around the world led to the formation of the main strategic goals in this industry, namely the high priority of ensuring the continuity and strength of supply chains in all sectors of the world economy. 
The trends in the logistics industry during the pandemic were associated with a decrease in cargo flow, both globally and locally, caused by the massive closure of borders of countries, shopping centers and stores, an increase in uncertainty and panic among the population, economic instability, an increase in currency quotes and a decrease in demand. and the purchasing power of a large proportion of the world's population. All presented trends are caused by drastic measures to combat the spread of COVID-19, which in turn caused the closure of many factories, factories around the world for quarantine in order to adhere to sanitary standards and recommendations of the Ministry of Health in this regard, there were no goods for transportation, and logistics also sucked out. Based on this, it is necessary to consider the main trends in the logistics industry during the pandemic, which served as the impetus for generating global chaos in the field of logistics services around the world.

The main factor that influenced the global logistics system was the aggravation of the crisis phenomena associated with the spread of the COVID-19 pandemic in China. In China, all types of transportation were affected: air, sea, rail, road, as a result of which the usual multimodal logistics schemes around the world were destroyed. However, this collapse did not last long and the Chinese authorities quickly stabilized the situation, which was ensured around the clock by many companies, logistics centers and organizations. Operators in the Chinese market have tried to respond flexibly to the situation, deploying emergency feeder services in difficult conditions. In general, in a short period of time, the supply chains were partially restored, which helped reduce uncertainty and panic in global markets [15].

However, not in all countries of the world, the stabilization of the logistics activity and the industry has come as well as in China. The economies of the EU countries are currently experiencing all the consequences of quarantine measures and interruptions in the supply of certain groups of goods. The movement of freight transport was not completely closed. However, there are certain restrictions since the number of infected people is not decreasing. These factors, on average, have already affected the economy of this group of countries, which is accompanied by a drop in economic growth by at least $40 \%$. In many countries, there are support programs and strategic partnerships that make it possible to soften the impact of the crisis and economic downturn.

Based on the above, it is worth considering the share of losses of companies in the logistics complex in the world, $\%$ as a result of massive restrictive measures associated with the COVID-19 pandemic, which are presented in Figure 1.

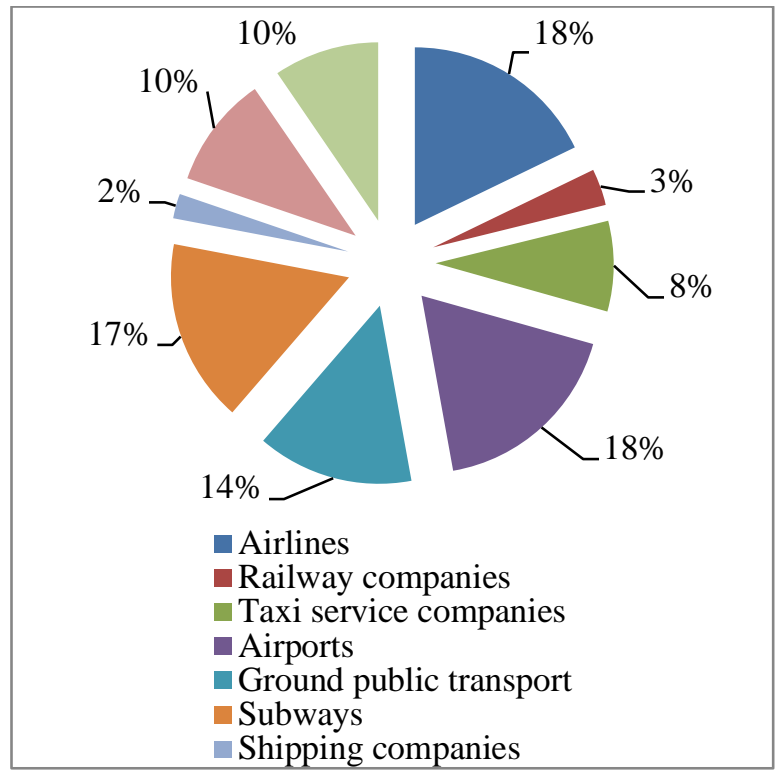

A) in $\%$

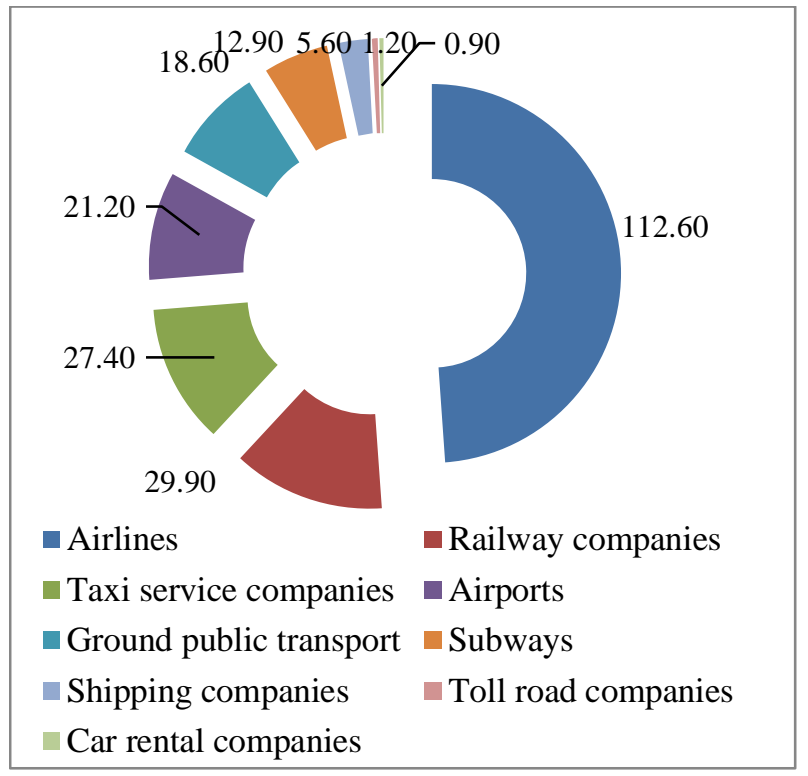

B) in billion US dollars

Figure 1 The share of losses of companies in the logistics complex in the world due to the restrictive measures of the pandemic

From the presented structure of losses of companies in the logistics complex around the world, it is worth noting that airlines and airports suffered the most, which lost about $\$ 270$ billion in 2019-2020 in the USA. The greatest losses were incurred by international air transportation, which is associated with the uncertainty of this industry since the flight schedule directly depends on the epidemiological and political situation in the separate countries. Also, this led to a decrease in cargo traffic, which is why many airlines have increased the cost of services by at least two times. A cyclical recession is observed in railway transportation. However, there are positive shifts that are inherent in this complex and associated with the fact that in many countries, transportation is stimulated by the provision of separate discounts and mutual partner settlements to maintain 
uninterrupted supplies, which is not insignificant in modern business conditions and ensures the effectiveness of the organization of marketing activities in this direction. It is worth noting that despite the closure of the borders in the segment of container transportation using sea transportation, there is slight growth and positive dynamics, but there are a number of uric moments in the direction of danger, which are associated with a reduction in the shipment of goods and goods to the East from Europe due to the complication of the situation with the pandemic. It should be noted that this type of logistics complex has historically always been volatile and uncertain due to the focus on imports. However, it is worth noting that during the period of the COVID-19 pandemic, the volume of maritime transport throughout the world has grown significantly, which will ensure a rapid recovery of previous volumes and economic growth of the industry before the crisis [16]. The very peak of the pandemic's activity in Europe was one of the key reasons for the cancellation of the exit of ocean-going ships from Southeast Asia, since it is impossible to process ship lots in
European ports - this was the main reason for the presented share of losses in this direction.

The coronavirus epidemic has also affected trucking. Huge queues at the borders in almost all countries have significantly increased the delivery time of goods, thus reducing the volume of income received and reducing economic growth in this industry. The current situation has led to the need to reduce the frequency of departures of individual flights and rebuild routes. Due to the lack of transport, the cost of transportation increased almost 2 times, which is associated with the need for uninterrupted functioning, taking into account all sanitary standards and delivery times. All the factors presented will significantly complicate the process of doing business, and the massive restrictions associated with the pandemic made it necessary to search for new innovative approaches for organizing the logistics activities of companies. There are many factors that determine the need for the development of companies in the logistics industry during the spread of the pandemic, which are worth considering in more detail, which are presented in Figure 2.

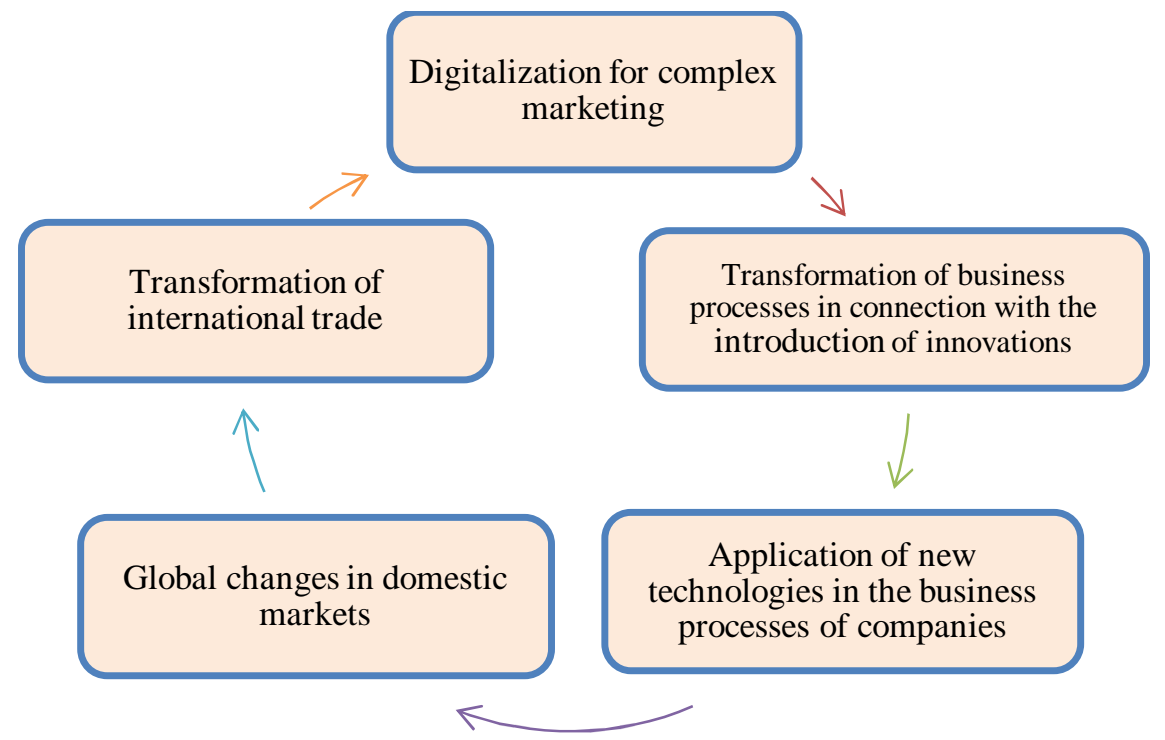

Figure 2 The share of losses of companies in the logistics complex in the world due to the restrictive measures of the pandemic

It should be noted that the presented factors make it possible to argue for the fact that the transport and logistics industry is going through a stage of transformation, which is determined by the emergence of new technologies and market trends. However, in recent years of the development of the global economic sector in the field of logistics, there has been no large-scale impact on the transport industry of political, economic, social, technological, environmental and legal changes [17,18]. In modern conditions, transport and logistics systems are constantly becoming more complex, and it is becoming more difficult to understand what should be paid attention to, especially in the context of aggravating crisis phenomena and the spread of a pandemic. Based on this, to determine the key trends in the functioning and interaction of marketing and logistics, it is worth using the tools of scenario economic and mathematical modeling. In the theory of economic and mathematical modeling, a mathematical function is used to determine development trends:

$$
D_{x i}=f\left(M\left(\mathrm{x}_{i}\right), L\left(\mathrm{x}_{i}\right)\right)
$$

Де, $D_{x i}$ - modern trends in the development of marketing and logistics and their interaction in a pandemic, which are compared simultaneously with actions $\left\{\mathrm{X}_{\mathrm{i}}\right\}$;

$M\left(\mathrm{x}_{i}\right)$ - the likelihood of a crisis event occurring when taking action $\left\{\mathrm{X}_{\mathrm{i}}\right\}$; 
$L\left(\mathrm{x}_{i}\right)$ - financial losses that are caused by the realization of risk, which with actions from multiple events $\left\{\mathrm{X}_{\mathrm{i}}\right\}$;

The spread of the pandemic worldwide, which is characterized by preventive and restrictive measures introduced in various countries of the world, contributes to the transformation of the logistics industry around the world. The spread of the pandemic around the world, which is characterized by preventive and restrictive measures that have been introduced in various countries of the world, which in turn contributes to the transformation of the logistics industry around the world. On this basis, in order to determine modern trends in the development of marketing and logistics, it is worth classifying countries by the level of the logistics efficiency index (LPI).
The Logistics Performance Index (LPI) is an interactive tool that is essential for benchmarking and classifying countries around the world by the level of development of the logistics industry and its efficiency. This index is a weighted average for the countries of the world by key parameters, such as the efficiency of customs, quality of logistics services, ease of organizing delivery and transportation, quality of logistics, tracking of shipments and deliveries of goods. According to countries' assessments, using this index, it is possible to determine with what ease and efficiency the logistics complex exist. The main scenarios of economic and mathematical modeling of modern trends in marketing and logistics and the peculiarities of their interaction during the spread of the pandemic on a global scale are presented in table 5.

Table 5 Main scenarios of economic and mathematical modelling of modern trends in marketing and logistics and features of their interaction during a pandemic

\begin{tabular}{|c|c|c|}
\hline $\begin{array}{c}\text { Scenarios of economic and } \\
\text { mathematical modeling of the level } \\
\text { of logistics development }\end{array}$ & $\begin{array}{c}\text { Graduation of the } \\
\text { logistics efficiency } \\
\text { indicator }\end{array}$ & Features of development and functioning \\
\hline $\begin{array}{c}\text { Optimistic development scenario } \\
\text { Pesimistic scenario of development }\end{array}$ & $3.02-5.00$ & $\begin{array}{l}\text { Intensive development of the logistics complex, } \\
\text { taking into account the transformation of the } \\
\text { world market under the influence of the } \\
\text { pandemic and factors that have a negative impact } \\
\text { on the functioning of marketing activities and its } \\
\text { relationship with logistics. }\end{array}$ \\
\hline $\begin{array}{c}\text { Critical development scenario } \\
\text { requiring anti-crisis management }\end{array}$ & $\begin{array}{l}\text { The functioning of the logistics complex is } \\
\text { accompanied by a number of global problems } \\
\text { that have negative consequences and give rise to } \\
\text { crisis phenomena in the activities of both } \\
\text { individual companies and the industry as a } \\
\text { whole. }\end{array}$ \\
\hline \multicolumn{2}{|c|}{$\begin{array}{l}\text { Realized risks in the field of the logistics } \\
\text { complex, both in an individual country and in } \\
\text { entire regions, which require the introduction of } \\
\text { support and the development of an anti-crisis } \\
\text { partnership in order to reduce the proportion of } \\
\text { financial losses that are caused by factors of } \\
\text { macroeconomic influence. }\end{array}$}
\end{tabular}

Logistics Performance (LPI) is a weighted average of a country for six key dimensions that will be used to classify countries by scenarios for the development and interaction of marketing and logistics during a pandemic [18].

The key parameters of scenario economic and mathematical modeling of trends in the development of marketing and logistics and the peculiarities of their relationship during a pandemic are the following:

The efficiency of the country's customs service (speed and availability of customs clearance of cargo transportation);
- Optimal and high-quality trade and transport infrastructure;

- Competitive pricing and ease of transportation;

- High professional training of employees of the logistics complex, which in turn allows to optimize the business processes of companies;

- $\quad$ Tracking tools for shipments and deliveries of goods and cargo;

- The quality and efficiency of delivery to the destination within the announced delivery time. 


\section{MARKETING AND LOGISTICS: FEATURES OF FUNCTIONING DURING THE PANDEMIC}

Hassan Ali Al- Ababneh

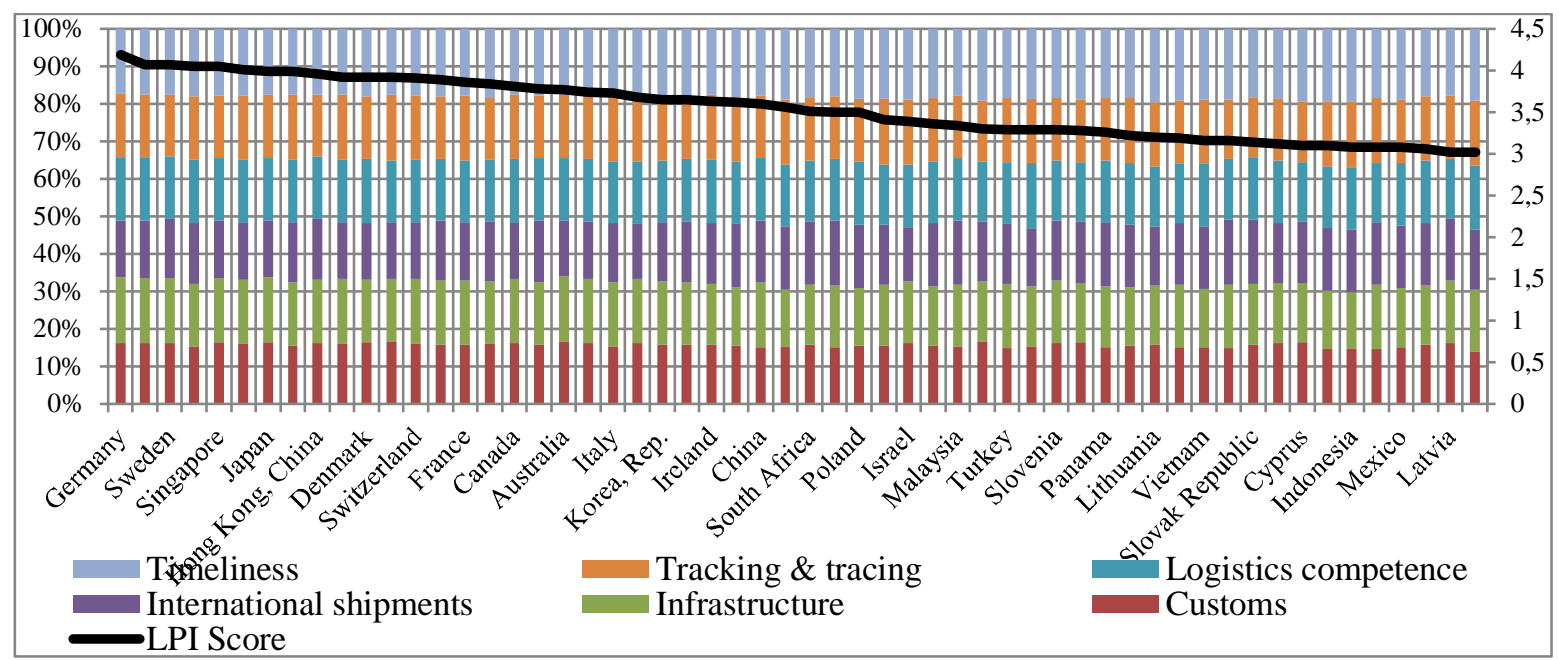

\section{A) Optimistic development scenario}

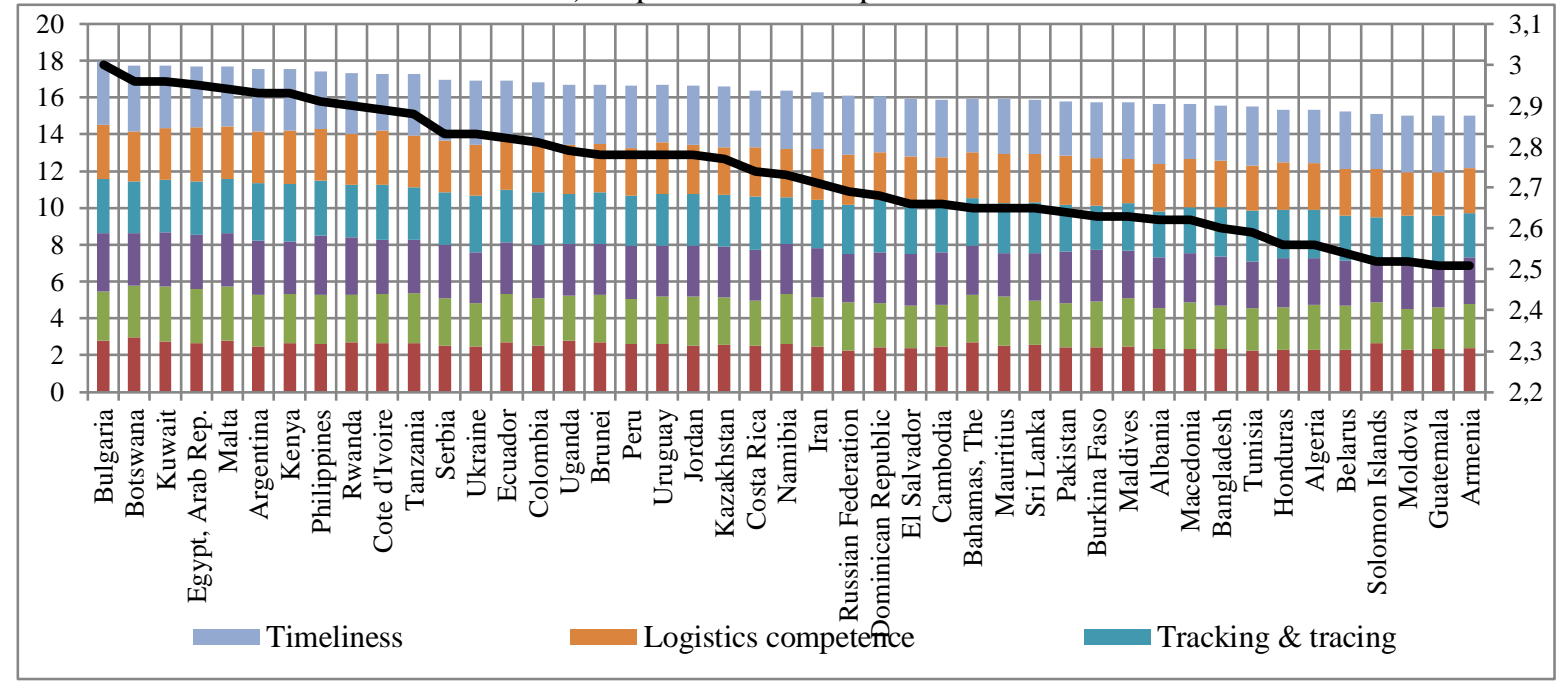

B) Pesimistic scenario of development

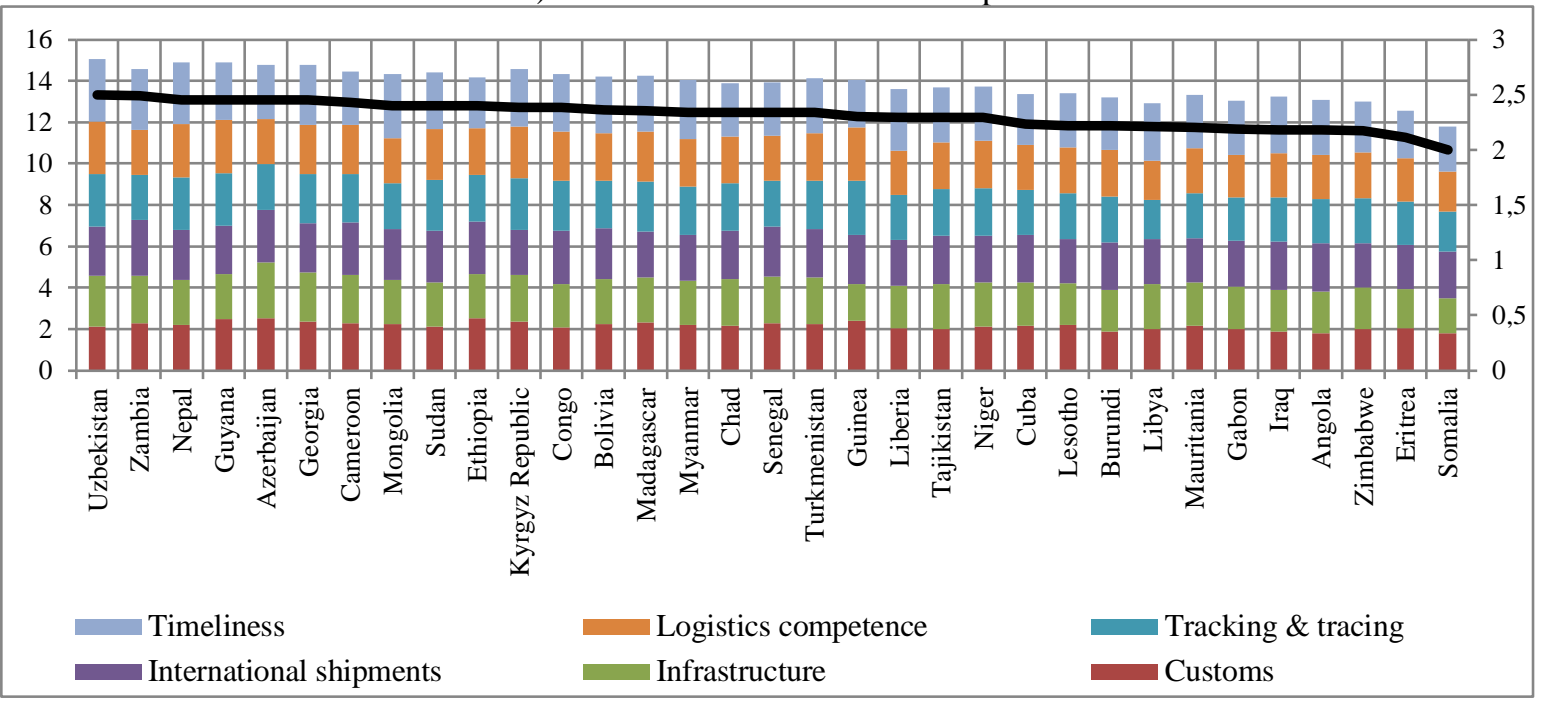

C) Critical development scenario requiring anti-crisis management

Figure 3 The main results of scenario modeling of the peculiarities of the functioning of marketing and logistics and their main interrelationships in a pandemic, in \% 
Based on the above, it is worthwhile to conduct scenario modelling of the features of the functioning of marketing and logistics and their main interrelationships in the current conditions of the spread of a pandemic. To do this, it is worth calculating the logistics efficiency index for all countries of the world and, based on the results obtained, classify each country based on which development scenario is most suitable for the ranges of indicators. The presented results of scenario modelling indicate that modern trends in the development of logistics complexes within the framework of the organization of the modern concept of marketing are characterized by the fact that in many countries, this development is carried out according to an optimistic forecast. This is because in these countries, the logistics efficiency index is in the range from 3.02 to 5, which is characterized by a high level of management and decision-making under the influence of factors caused by the pandemic. The main results of scenario modelling of the peculiarities of the functioning of marketing and logistics and their main interrelationships in a pandemic are shown in figure 3.

\section{Conclusions}

Logistics in modern business conditions is becoming a real organizational, technological and conceptual support for many companies and is the most effective tool for future development. It has been shown that logistics is a key instrument in the modern marketing strategy, without which it is impossible to manufacture and increase the company's capacity without positioning it and improving its competitive position in the world market. However, not all countries are characterized by the optimistic development of the logistics complex, which is evidenced by the fact that according to the pessimistic scenario of logistics development in the marketing complex, most countries are currently functioning. This group of countries is on the border between two scenarios, both optimistic and crisis, which depends on the effectiveness of management and the propensity to accept the level of risks that are caused by the pandemic. It is worth noting that the main results of the study of the dynamics of the development of marketing and logistics, as well as their interaction, as the main component of a modern company, indicate that in many countries now, the management of logistics is in a state of crisis, which is caused by a pandemic. However, to increase the volume of freight traffic in all countries, an adequate strategy for future development is needed, which includes an innovative marketing complex, which is not possible without logistics.

The theoretical and methodological aspects were developed to determine the interaction of marketing and logistics during the COVID-19 pandemic, which made it possible to substantiate the main components of the marketing concept for doing business, ensuring efficiency and financial stability of the organization. The features of the functioning of logistics on a global scale have been considered, which made it possible to substantiate the classification of key factors that influenced the transformation of logistics activities in the world. Based on scenario economic and mathematical modelling, the functioning of marketing and logistics during the COVID19 pandemic is determined. The study's main results can be applied in the practical activities of organizations in the formation of a development strategy and marketing concept.

\section{References}

[1] AL-ABABNEH, H.A.: Integrated approach in organizing logistic activity, Acta logistica, Vol. 7, No. 4, pp. 235-243, 2020. doi:10.22306/al.v7i4.184

[2] MADHANI P.M.: Logistics and marketing integration: enhancing competitive advantages, The IUP Journal of Management Research, Vol. 16, No. 3, pp. 7-29, 2017.

[3] POKUSA, T.: Logistics-marketing management: goals and effects, Journal of Modern Economic Research, Vol. 3, No. 2, pp. 27-39, 2020.

[4] DEFEE, C., WILLIAMS, B.D., WESLEY, S.R., THOMAS, R.W.: An inventory of theory in logistics and SCM research, The International Journal of Logistics Management, Vol. 21, No. 3, pp. 404-489, 2010. doi:10.1108/09574091011089817

[5] WALKER, O.: Logistic management, Boston, Kent Publishing Company, 2002.

[6] MCKINNON, A.: Integrated logistics strategies, Handbook of logistics and supply-chain management, Emerald Group Publishing Limited, 2008.

[7] RÜZGAR, N.: Management and Organization in Transportation and Logistics, Handbook of Research on the Applications of International Transportation and Logistics for World Trade, 2020.

[8] NOORLIZA, K.: Resource-capability of halal logistics services, its extent and impact on performance, Journal of Islamic Marketing, Vol. 12, No. 4, pp. 813-829, 2020. doi:10.1108/JIMA-12-2019-0255

[9] AL-ABABNEH, H.A., DALBOUH, M.A.A.: Supply Chain Risk Management Methods in the Process of Formation of Advertising Campaign, International Journal of Supply Chain Management, Vol. 9, No. 2, pp. 779-785, 2020.

[10] AUTRY, C.W.: Supply chain research: considering the discipline's evolving relationship with marketing, current issues, and future research directions, Journal of Marketing Theory and Practice, Vol. 29, No. 1, pp. 1-13, 2021. doi:10.1080/10696679.2020.1860684

[11] DROBIAZGIEWICZ, J.: Marketing logistics management in e-retail-the essence and selected practical aspects, European Journal of Service Management, Vol. 27, No. 3, pp.149-155, 2018. doi:10.18276/ejsm.2018.27/2-18

[12] SPERANZA, M.G.: Trends in transportation and logistics, European Journal of Operational Research, Vol. 264, No. 3, pp. 830-836, 2018.

[13] HE, Z., CHEN, P., LIU, H., GUO, Z.: Performance measurement system and strategies for developing 
low-carbon logistics: A case study in China, Journal of Cleaner Production, Vol. 156, No. July, pp. 395405, 2017.

[14] HECKMANN, G.: Identifying underlying urban logistics factors in old downtown of Córdoba, Argentina, Supply chain management and logistics in emerging markets, Emerald Publishing Limited, 2020.

[15] HENRIKSSON, L.E., CHOW, G., HEAVER, T.D.: Trends in logistics: implications for carriers, researchers and policymakers, 29th Annual Canadian Transportation Research Forum, Vancouver, British Columbia, May 15-18, 1994 305992, Canadian Transportation Research Forum (CTRF), 2020. doi:10.22004/ag.econ.305992
[16] CHO, H.: Does transportation size matter for competitiveness in the logistics industry? The cases of maritime and air transportation, The Asian Journal of Shipping and Logistics, Vol. 36, No. 4, pp. 214223, 2020.

[17] LPI GLOBAL RANKINGS 2019: [Online], Available: https://lpi.worldbank.org/international/glo bal/2019 No. 1, pp. 10-18, [12 Dec 2020], 2019.

[18] BOTTALICO, A.: The Logistics Labor Market in the Context of Digitalization: Trends, Issues and Perspectives, Digital Supply Chains and the Human Factor, Springer, Cham, 2021.

Review process

Single-blind peer review process. 